Kurudayıoğlu, M. (2019). Yabancı dil olarak Türkçe ders kitaplarındaki konuşma etkinliklerinin konuşma türleri açısından İncelenmesi. Ana Dili Eğitimi Dergisi, 7(3), 736-750.

\begin{tabular}{c} 
Ana Dili Eğitimi Dergisi \\
Journal of Mother Tongue Education \\
www.anadiliegitimi.com \\
$\begin{array}{c}\text { Geliş/Received: } 13.05 .2019 \text { Kabul/Accepted:23.07.2019 } \\
\text { Araşttrma Makalesi / Research Paper }\end{array}$ \\
\hline
\end{tabular}

\title{
Yabancı Dil Olarak Türkçe Ders Kitaplarındaki Konuşma Etkinliklerinin Konuşma Türleri Açısından İncelenmesi*
}

\author{
Mehmet KURUDAYIOĞLU**
}

\begin{abstract}
Öz
Bu araştırma, yabancı dil olarak Türkçenin öğretimi kitap setlerinde konuşma etkinliklerinin hangi konuşma türlerinin öğretimine yönelik olarak tasarlandığını ortaya koymayı amaçlayan nitel bir çalışmadır. Araştırmada, bu amaca ulaşmak ve veri toplamak için doküman incelemesinden yararlanılmıştır. Araştırmanın inceleme nesnesini temel düzeyi temsilen Yedi İklim ve İstanbul setlerinden A1 düzeyi kitapları, orta düzeyi temsilen B1 düzeyi kitapları ve ileri düzeyi temsilen C1 düzeyi kitapları oluşturmaktadır. Veriler içerik analizi kullanılarak çözümlenmiştir. İçerik analizi sonucunda elde edilen veriler frekans hesaplamaları kullanılarak sınıflandırılmıştır. İnceleme neticesinde temel, orta ve ileri düzey yabancılara Türkçe öğretimi kitaplarında bulunan hazırlıklı konuşma etkinliklerine göre hazırlıksız konuşma etkinliklerinin nicel olarak çok düşük olduğu görülmüştür. Bu sonuçtan hareketle hazırlıklı ve hazırlıksız konuşma etkinliklerinin sayısında bir denge gözetilmesi önerilmektedir
\end{abstract}

Anahtar Kelimeler: Yabancı dil olarak Türkçe öğretimi, konuşma eğitimi, etkinlik, konuşma türleri,

\section{Examination of Speaking Activities in Turkish as a Foreign Language Coursebooks in Terms of Speech Types}

\begin{abstract}
This research is a qualitative study aiming to reveal which speech types are designed for teaching speaking in book sets of teaching Turkish as a foreign language. In this research, document analysis was used to reach this aim and to collect data. The research object consists of A1 level books representing the basic level, B1 level books representing the intermediate level and C1 level books representing the advanced level of Yedi Iklim Publishing and Istanbul Publishing sets. The data were analyzed using content analysis. The data obtained by content analysis were classified according to frequency rates. As a result of the study, it was seen that unprepared speaking activities were very few compared to prepared speaking activities in basic, intermediate and advanced foreign language teaching books. Based on this result, it is recommended to balance the number of prepared and unprepared speaking activities.
\end{abstract}

Keywords: Teaching Turkish as a foreign language, speaking education, activity, speech types,

Giriş

İnsana özgülüğü nedeniyle insan olmanın en belirleyici özelliklerinden olan konuşma, bireylerin yaşamlarını sürdürmelerinde önemli bir role sahiptir. Konuşma, insanın çevresi ile iletişim kurmasında en etkili araçtır. Bireyler, konuşma becerileri vasıtasıyla toplum içerisinde iletişim kurabilirler. Toplum

\footnotetext{
* 25-28 Eylül 2018 tarihlerinde Polonya'nın Varşova şehrinde düzenlenen “13. Uluslararası Büyük Türk Dili Kurultayı"nda bildiri olarak sunulmuştur.

** Doç. Dr, Hacettepe Üniversitesi Eğitim Fakültesi Türkçe ve Sosyal Bilimler Eğitimi Bölümü, Ankara, mkurudayioglu@hacettepe.edu.tr, ORCID: 0000-0002-0447-5236
} 
hayatının hemen hemen her yerinde konuşma faaliyetleri bulunmaktadır. İçinde bulunduğumuz yaşam alanlarında iletişim türü büyük ölçüde konuşmaya dayalıdır. Bireylerin günlük hayat içerisinde birbirleriyle anlaşmalarında, gereksinimlerini gidermelerinde ve daha birçok yaşam faaliyetlerini gerçekleştirmelerinde konuşmanın önemi tartışılamayacak derecede büyüktür. Çünkü konuşma, insanın varoluşundan kaynaklanan en temel özelliklerinden birisidir.

Alanyazında konuşmanın birçok tanımı bulunmaktadır. Konuşma, "düşüncelerin, duyguların ve bilgilerin seslerden oluşan dil aracılığıyla aktarılmasıdır." (Demirel, 1999:40). "Başka bir ifade ile bir konunun zihinde tasarlandıktan sonra karşımızdakilere sözle iletilmesidir" (Sever, 2004:22). "Konuşma kişinin isteklerini, düşüncelerini sözle bildirmesidir." (Göğüş, 1978:174). “Konuşma bir düşünce alışverişi, başka türlü söylemek gerekirse yaşantılarımızı başkalarıyla paylaşma işidir" (Kurudayıoğlu, 2013:3). Güneş (2014:3)'e göre ise; “Konuşma, duygu ve düşüncelerin sözlere aktarılması, zihinsel yapı, süreç ve işlemlerin açığa çıkarılması olarak açıklanmaktadır." Yukarıdaki tanımlardan hareketle konuşma; aktarılmak istenen duygu ya da düşüncenin zihinsel bir hazırlık sürecinden geçerek muhatabına sözlü olarak iletilmesi olarak tanımlanabilir.

İnsanın sözlü olarak kendini ifade etmesinde en önemli iletişim kanalı olan konuşma, eğitim sürecinde de ihmal edilmemesi gereken bir beceridir. Düşünen ve düşüncelerini iletişim kurduğu kişi ya da kişilere doğru ve etkili bir şekilde aktarabilen bireyler yetiştirmek için konuşma eğitimine gereken önem verilmelidir. Bu doğrultuda, eğitim ortamlarında konuşma becerisinin bilinçli ve sistematik bir biçimde geliştirilmesi gerekmektedir. Doğru ve etkili konuşma becerisinin bireylere kazandırılmasında eğitim yaşantılarının önemli bir rolü vardır. "Konuşma becerisini istenilen seviyeye yükseltecek olan, anlamlı, doğru ve etkili konuşma ilkelerini kazandıracak eğitim ve öğretim yaşantılarıdır." (Sağlam, 2010:14). Bu bakımdan konuşma eğitimi, eğitim süreci içerisinde ana dili derslerinin temel alanlarından biri olarak görülmektedir.

Etkili konuşma becerisinin eğitim yoluyla davranışa dönüştürülmesi ve etkili konuşma alışkanlığııın kazandırılması bireylerin yaşam deneyimlerini doğrudan etkilemektedir. Konuşma becerisi gelişmiş bireyler, bu vasıflarından dolayı toplum hayatında daha özgüvenli ve başarılı olurlar. Toplum içerisinde, kendilerini herhangi bir kaygı taşımadan, rahat ve akıcı bir şekilde ifade ederler. Anlatmak istediklerini muhataplarına anlaşılır bir şekilde aktarırlar. Bütün bunlar, bireylerin mutlu bir yaşam sürmesinde etkili olan faktörlerdir.

\section{Konuşma Türleri}

Konuşma türleri, konuşmanın kendine özgü amacı ve işlevi, sunuluş şekli ve konuşucu-dinleyici nitelikleri çerçevesinde sınıflandırılmaktadır. Konuşma türleriyle ilgili yapılan araştırmalar incelendiğinde, konuşmanın türlere ayrılmasında araştırmacılar arasında uzlaşı olmadı̆̆ı 
görülmektedir. Bazı araştırmacılar konuşmayı işleve göre sınıflandırarak ikna edici konuşma, güdümlü konuşma gibi türlere ayırırken, bazı araştırmacıların konuşucu niteliklerini ön plana alarak konuşmayı karşııklı ve tekil konuşmalar şeklinde sınıflandırdığı görülmektedir. Konuşmanın sunuluş şeklinin esas alan araştırmacılar ise konuşmayı hazırlıklı ve hazırlıksız konuşmalar olarak çeşitlendirmektedir. (Şimşek, 2004; Temizyürek, 2013; Yalçın, 2006).

Konuşma türlerini sınıflandırılması konusunda farklı görüşler mevcuttur. Taşer (2015), konuşma türlerini işlevlerine göre sınıflandırmaktadır. Ona göre konuşma türleri; günlük konuşma, tartışma, görüşme, konferans, söylev, demeç, yorumlayııı konuşma ve inandırıcı konuşmadır. Karadüz (2011), konuşma türlerini ikna etme, eleştirel konuşma, katılımlı konuşma, tartışma, empati kurma, güdümlü konuşma, kelime ve kavram havuzundan seçerek konuşma, serbest konuşma ve yaratıcı konuşma olarak belirtir. Avrupa Dilleri Ortak Çerçeve Metni ise konuşma türlerini, kamu ilanları ve talimatlar, topluluk huzurunda konuşmalar, dersler, sunumlar, vaazlar, ayinler, eğlence, spor yorumları, haber yayınları, halka açık münazaralar ve konuşmalar, kişilerarası diyaloglar ve sohbetler, telefon ve iş görüşmeleri olarak sınıflandırmaktadır. (CEF, 2002). Konuşma türlerini sunuluş biçimi açısından ele alan Yalçın (2006), konuşma türlerini hazırlıklı ve hazırlıksız olmak üzere iki ana gruba ayırır. Bir başka sınıflandırmaya göre ise konuşma türleri; ikna edici konuşma, betimleyici konuşma ve sorgulayıcı konuşmadır. (Güneş, 2013). Yukarıdaki farklı sınıflandırmaların çeşitliliğinden görüldüğü üzere, konuşma türlerinin sınıflandırılmasında araştırmacılar arasında bir uzlaşma bulunmadığı sonucu ortaya çıkmaktadır.

Bu araştırmada konuşma türleri sunuluş açısından ele alınarak, hazırlık ve hazırlıksız konuşmalar olmak üzere iki ana başlıkta incelenmiştir.

\section{Hazırlıksız Konuşmalar}

Hazırlıksız konuşmanın birçok tanımı yapılmıştır. Yalçın (2006:136)'a göre hazırlıksız konuşma, "kişinin günlük hayatı içinde herhangi bir ön hazırlık yapmadan evde, işyerinde dinlenme sırasında, ikili ilişkilerinin tümündeki konuşmalardır. Hazırlıksız konuşmalar, yaşam deneyimlerimiz sırasında en çok başvurduğumuz konuşma türüdür. Bu sebeple günlük konuşmalar olarak da adlandırılırlar. "Kişilerin karşılaştıkları sorunlara çözüm üretmek, içinde bulundukları olay ve durumlar hakkında yorum yapmak, kendi duygu ve düşünceleriyle ilgili açıklamalarda bulunmak, günlük hayatlarını devam ettirmek için birdenbire herhangi bir araştırmaya başvurmadan, iletişimin doğal süreci içinde gerçekleştirdikleri konuşmalar, hazırlıksız konuşmadır." (Sağlam, 2010, 50)

Hazırlıksız konuşmalar, yer ve zaman açısından düşünüldüğünde, hazırlıklı konuşmalara göre daha zordur. Konuşma beklenmedik bir yerde, beklenmedik bir zamanda ani olarak gerçekleşebilir. Ayrıca hazırlıksız konuşmalarda, ön hazırlık yapmak ve plan oluşturmak için uzun bir vakit 
bulunmamaktadır. Konuşmacının anlatacağı konuyu doğaçlama olarak sunması gerekir. Konunun doğaçlama olarak sunulması ön bilgilerin ve yaşam deneyimlerinin zenginliğiyle yetkinleştirilebilir. Bireyin bilgi donanımının fazla olması ve zengin yaşam deneyimleri, etkili bir hazırlıksız konuşma için önem taşımaktadır. Sever (1998:57) ise etkili bir hazırlıksız konuşma için şu ilkeleri vurgular:

1. Güven verici ve içten olmak

2. Canlı ve doğal olmak

3. Ölçülü olmak

4. Dilini iyi bilmek ve kullanmak.

Hazırlıksız konuşmalar temelde ayrıntılı bir plan ve uzun bir ön hazırlığa dayanmasa da bu tür konuşmalarda kısa bir hazırlık süreci olmaktadır. "Hazırlıksız konuşmada önemli olan, bu kısa hazırlık süresini en iyi şekilde kullanabilmek ve konuşma içeriğini doğru şekilde belirleyebilmektir." (Sağlam, 2010:51). Bu süreçte kullanılabilecek bazı stratejiler bulunmaktadır. Brayden ve Scott (2008), bunları şöyle sıralar:

1. Konuşma yapmak istediğimiz hususların belirlenmesi

2. Belirlenen hususların genişletilmesi

3. Anlatılanların özetlenmesi.

Hazırlıksız konuşmalar hayatın her alanında kişiyi çevrelemektedir. Günlük hayattaki iletişim süreçleri büyük ölçüde hazırlıksız konuşmalara dayalıdır. Ancak kişiler bazen topluluk karşısında hazırlıksız konuşma yapmak durumda kalabilir. Bazen beklenmedik bir anda kürsüye davet edilebilir. Böyle durumlarda doğru ve etkili hazırlıksız konuşmalar yapmayı başarabilmek tesadüfî bir süreç değildir. Hazırlıksız konuşmaları etkili kılmanın bazı yöntemleri bulunmaktadır. Bunlardan biri Laskowski'nin (2019) “TIQS" olarak kısalttığı “topic (konu), importance (önem), qualification, (nitelik), subject (özne)" yöntemidir. Örneğin, bir ödül töreni için hazırıksız konuşma yapıldığı düşünülürse, ilk adım ödülün konusu hakkında konuşmak, ikinci adım ödülün öneminden bahsetmek, üçüncü adım ödülün gerektirdiği nitelikleri ele almak ve son adım da ödüle layık görülen kişiden söz etmek olabilir. Bu yöntem asında anlatılmak istenen konunun farklı yönlerini sınıflandırması bakımından konuşmacıya kolaylıklar sağlamaktadır. Bir diğer yöntem de Brayden ve Scott (2008) tarafından şöyle ifade edilir:

1.Konuşma ihtimalinize karşı öngörülü olun, tedbiri elden bırakmayın.

2.Organize olun

3.Bir pozisyon alın

4.Etkili bir dil kullanın 
5. Otostop tekniğini kullanın (Başkalarının fikirleriyle başlayın)

6. Hikaye ve anekdot kullanın

7. Referans çalışmaya zaman ayırın.

Hazırlıksız konuşmalar kendi içinde sınıflara ayrılmaktadır. Temizyürek (2013), hazırlıksız konuşmaları "kendini tanıtma, tanışma ve tanıştırma, teşekkür etme-özür dileme, telefonda konuşma, ziyaret, karşılama ve uğurlama konuşmaları, selamlaşma konuşmaları, yol sorma, yol tarif etme konuşmaları, tanıtma (takdim) konuşmaları, anma ve yıl dönümleri konuşmaları, açış konuşmaları, sunuş konuşmaları, sohbet konuşmaları, fıkra anlatımı, soru sorma ve sorulara cevap verme ve görevlilerle yapılan konuşmalar" olarak 16 alt başlıkta ele almıştır. Kişilerin günlük yaşam deneyimleri içerisinde karşılaşabileceği bu türler, konuşma eğitimi sürecine dahil edilmeli, hazırlıksız konuşma türleri geniş bir yelpaze içinde eğitim-öğretim ortamlarında yer almalıdır.

\section{Hazırlıklı Konuşmalar}

Önceden belirlenen bir zaman ve mekânda, belli bir ön hazırlık süreci içerisinde yapılandırılan ve planlı bir şekilde dinleyicilere aktarılan konuşma türüdür. "Nerede, ne zaman yapılacağı, konusu ve amacı daha önceden bilinen, belli bir plana göre hazırlanarak yapılan konuşmalardır." (Yüceer, 2014:38). Hazırlıklı konuşmalar; "konuşma yeri ve zamanı önceden belirlenerek değişik insan toplulukları karşısında yapılan konuşmalardır." (Temizyürek, 2013). Bir başka tanıma göre, kişinin önceden planlama yaparak bilgi, belge ve teknik detayları sentezleyerek yaptığı konuşmalardır. (Yalçın, 2006). Bu tür konuşmalarda genellikle konuşma konusu dinleyiciler tarafından da bilinmektedir. Dinleyiciler, önceden belirlenmiş olan konu hakkında bilgi edinmek amacıyla konuşmayı dinlerler.

Hazırlıklı konuşmalar, hazırlıksız konuşmaların aksine bir hazırlık süreci gerektirmektedir. Bu bakımdan konuşulacak konunun belirlenmesi, konunun gerekli görülen yönlerinin araştırılması ve bir plan dâhilinde toplanan bilgilerin yapılandırılması etkili bir hazırlıkı konuşma için elzemdir. İyi bir hazırlık sürecinden sonra ikinci aşama konuşmanın sunulmasıdır. Bu noktada sesi doğru ve etkili kullanmanın, vurgu ve tonlamaya özen göstermenin, dilin doğru kullanımının ve jest ve mimik gibi beden dili unsurlarının doğru kullanımı oldukça önemlidir.

Temizyürek (2006)'e göre, hazırlıklı konuşmalar “konferans, aytışma (münazara), sempozyum, panel, forum, açık oturum, söylev (nutuk), röportaj ve mülakat" olmak üzere 9 alt başlıkta incelenmektedir.

1. Konferans: Alanında uzman kişiler tarafından, belli bir dinleyici kitlesine bilgi vermek amacıyla yapılan hazırlıklı konuşma türüdür. "Bilimsel bir düşünceyi, akademik bir konuyu, orijinal bir görüşü anlatmak, bir tezi savunmak konferansın en belirgin amacıdır." (Ünalan, 2007). Konferansın 
konusu dinleyici kitlesinin intiyaçlarına göre belirlenir. Bu ihtiyaçlar doğrultusunda alanında uzman bir konuşmacı tarafından konferans verilir.

2. Aytışma (Münazara): Bir konu hakkında karşıt görüşlerin karşlıklı olarak savunulmasına dayanan hazırlıkı konuşma türüdür. "Münazara, önceden belirlenen bir konunun jüri ve dinleyici topluluğu önünde karşıt görüşten iki grup tarafından tartışılma biçimidir (Demirel, 2011). Münazara, fikirlerin ve sözlerin yarıştırılmasıdır. Münazarada karşıt gruplar kendi fikirlerini savunarak diğerinin fikirleri çürütmek için gösterirler. Bu bakımdan münazaralar, tez ve onu antitezinden oluşan fikirler etrafında şekillenir.

Eğitim alanında münazaradan belirli eğitsel amaçlar için yararlanılır. Türkçe eğitimi açısından bakıldığında, derslerde münazara etkinliklerinin yapılmasının sebebi öğrencilerin konuşma becerilerini ve eleştirel düşünce yetilerini geliştirmektedir.

3. Sempozyum: "Bir konunun çeşitli yönlerinin, aynı oturumda alanlarında uzman olan değişik konuşmacılar tarafından sırayla ortaya konduğu tartışmalı toplu konuşmalardır." (Ünalan, 2007:96). Genellikle bilimsel bir amaçla gerçekleştirilir. 3-6 kişiden oluşan konuşmacılar, 5-15 dakika süreyle konuşurlar. Sempozyumda amaç bir konuyu derinlemesine ele almaktadır.

Sempozyum, katılımcı sayısına göre aynı birden fazla oturumlarda yapılmaktadır. Her oturumda bir oturum başkanı bulunur. Oturum başkanının görevi oturumları yöneterek, konuşmacıların sunumlarını belirli süre içinde bitirmesini sağlamaktır.

Sempozyumlarda sunulan konuşma metinlerine bildiri adı verilir. Sempozyum düzenleme kurulu, istenildiği taktirde sempozyum kapsamında sunulan bildirileri bir kitap olarak düzenleyerek yayımlayabilir.

4. Panel: Herhangi bir konunun alanının uzmanları tarafından bir başkan yönetiminde ve dinleyiciler önünde çeşitli yönleriyle ele alındığı hazırlıklı konuşmalardır. "Bir başkanın yönetiminde, küçük bir tartışmacı grubunun izleyiciler önünde belli bir konuya ilişkin görüş ve düşüncelerini belirttikleri grup tartışmasıdır" (Ünalan, 2007, 94). Ele alınan konu tartışılmaktan ziyade birçok yönden incelenmeye çalışılır.

Özkırımlı (2002), paneli açık oturuma benzetmektedir. Panelin açık oturumdan farkı, konuşmacı sunumlarından sonra dinleyicilere de söz verilmesi ve dinleyicilerin de görüşlerini açıklama fırsatlarının olmasıdır. Dinleyiciler sorularını sözlü ya da yazılı olarak sunabilmektedir.

5. Forum: "Forum, bir konuda çok sayıda kişinin çok farklı görüşlerini bildirdiği konuşma şeklidir" (Gülsevin ve Boz, 2006:275). Belli bir konuda ortaklığı bulunan bir grubun, ortak sorunlarının 
çözümlenmesinde görüş birliğine varmak üzere düzenlenen toplu tartışmaya forum denir. (Ünalan, 2007). Forumda nihai amaç, üzerinde konuşulan konuda bir mutabakata varmaktadır.

Forum da bir başkan tarafından yönetilir. Forum konuşmacılarının eşit söz hakkı alması, katılımcı sayısının çok olması ve ele alınan sorunların çözümüne dair ortak bir anlayış geliştirilmesinde başkanın sorumluluğu bulunmaktadır. Forum başkanlığı bu bakımdan diğer hazırlıklı konuşma türlerindeki başkaların görevinden daha zordur.

6. Açık Oturum: Toplumu ilgilendiren siyasi, sosyal ya da kültürel bir konunun değişik görüşlerdeki 3-5 kişiden oluşan bir konuşmacı grubu tarafından dinleyiciler önünde tartışılmasıdır. Açık oturum, toplumu yakından ilgilendiren güncel bir konunun değişik görüşlerdeki uzman kişiler tarafından seçkin bir izleyici önünde tartışılmasıdır (Ünalan, 2007). Açık oturumun amacı, belirli bir konunun farklı yönlerini ele almaktadır.

Açık oturumda da bir başkan ve en az 3 konuşmacı bulunur. Başkan, oturum sonunda konuşmaları özetler. Açık oturumda dinleyiciler tartışmaya katılamaz. Açık oturum süresince her konuşmacıya eşit söz hakkı tanınması gerekir.

7. Söylev (Nutuk): Söylev, Türkçe Sözlük’te “Bir topluluğa düşünceler, duygular aşılamak amacıyla söylenen, uzunca, coşkulu ve güzel söz, nutuk, hitabe” biçiminde tanımlanmaktadır. (TDK, 1996:2022). Söylev, diğer birçok hazırlık konuşma türünün aksine bireysel olarak yapılmaktadır. Söylevde dinleyiciler aktif değildir ancak dinleyicilerin coşkusu konuşmaya yön verir. Söylevlerin, işledikleri konulara göre siyasi, askeri, dini ve hukuki gibi sıfatlar alabilir. (Temizyürek, 2013).

8. Röportaj: Herhangi bir yeri, kişiyi, toplumsal, kültürel, ekonomik vb. durum, olay ve olguları çeşitli yönleriyle tanıtmak amacıyla ilgililerle yüz yüze görüşerek, onların gözlemlerini, bilgilerini, yorumlarını aktaran türe röportaj adı verilmektedir. (Temizyürek, 2013). Röportaj, ilgili konunun uzmanıyla soru-cevap biçiminde yapılır.

Röportaja başlamadan önce ciddi bir ön hazırlık süreci vardır. Konu seçimi, seçilen konu hakkında araştırma yapııması, araştırmalar sonucunda da röportaj sorularının hazırlanması nitelikli bir röportaj için önemli adımlardır.

9. Mülakat (Görüşme): Mülakat, röportaj türünün daha özel bir biçimidir. "Toplum tarafından merak edilen ünlü kişileri tanımak ve topluma tanıtmak, toplumu ilgilendiren önemli bir konuyu aydınlatmak üzere ünlü kişilerle veya uzmanlarla yapılan konuşmalardan elde edilen sonuçları aktarmak amacıyla yapılan görüşmelere mülakat denir." (Temizyürek, 2013, 184). Mülakat genellikle toplum tarafından ilgi duyulan sanat, siyaset ya da spor dünyasında tanınmış önemli kişilerle yapılır. 


\section{Yöntem}

Bu araştırma, yabancı dil olarak Türkçenin öğretimi kitap setlerinde konuşma etkinliklerinin hangi konuşma türlerinin öğretimine yönelik olarak tasarlandı̆̆ını ortaya koymayı amaçlayan nitel bir çalışmadır. Araştırmada, bu amaca ulaşmak ve veri toplamak için doküman incelemesinden yararlanılmışır. Araştırmanın inceleme nesnesini temel düzeyi temsilen Yedi iklim ve İstanbul setlerinden A1 düzeyi kitapları, orta düzeyi temsilen B1 düzeyi kitapları ve ileri düzeyi temsilen C1 düzeyi kitapları oluşturmaktadır. Veriler içerik analizi kullanılarak çözümlenmiştir. "içcerik analizi, sözel, yazılı ve diğer materyallerin nesnel ve sistematik bir şekilde incelenmesine olanak tanıyan bilimsel bir yaklaşımdır." (Sert vd., 2012). İçerik analizi sonucunda elde edilen veriler frekans hesaplamaları kullanılarak sınıflandırılmıştır.

\section{Bulgular}

Bu bölümde araştırmanın bulguları yer almaktadır.

Tablo 1. Temel Düzey Yabancılara Türkçe Öğretimi Kitaplarında Konuşma Türlerinin Görünümü

\begin{tabular}{|c|c|c|c|c|c|}
\hline HAZIRLIKLI & Y.İklim & İstanbul & HAZIRLIKSIZ & Y. İklim & İstanbul \\
\hline KONUŞMALAR & & & KONUŞMALAR & & \\
\hline Konferans & - & - & Kendini Tanıtma & - & - \\
\hline Münazara & - & - & Tanışma ve Tanıştırma & 3 & - \\
\hline Sempozyum & - & - & Teşekkür-Özür & - & - \\
\hline Panel & - & - & Telefonda Konuşma & - & - \\
\hline Forum & - & - & Ziyaret & - & - \\
\hline Açık Oturum & - & - & Karşılama ve Uğurlama & - & - \\
\hline Söylev & - & - & Selamlaşma Konuşmaları & - & - \\
\hline Röportaj & 1 & - & Yol Sorma, Yol Tarifi Konuşmaları & 2 & 1 \\
\hline \multirow[t]{8}{*}{ Mülakat } & - & - & Tanıtma Konuşmaları & 2 & 4 \\
\hline & & & Anma ve Yıldönümü Konuşmaları & - & 1 \\
\hline & & & Açış Konuşmaları & - & - \\
\hline & & & Sunuş Konuşmaları & - & 2 \\
\hline & & & Sohbet Konuşmaları & 8 & - \\
\hline & & & Fikra Anlatmak & - & - \\
\hline & & & $\begin{array}{l}\text { Soru Sorma ve Sorulara Cevap } \\
\text { Verme Konuşmaları }\end{array}$ & 16 & 17 \\
\hline & & & Görevlilerle Yapılan Konuşmalar & - & - \\
\hline Toplam & 1 & 0 & Toplam & 31 & 25 \\
\hline
\end{tabular}

Temel düzey Yedi İklim kitaplarında hazırlıksız konuşmalar; tanışma ve tanıştırma, yol sorma, yol tarif etme, sohbet konuşmaları ve soru sorma, sorulara cevap verme konuşmaları olmak üzere 5 farklı türde ele alınırken, hazırlıklı konuşmalar sadece bir röportaj örneğiyle sınırlı kalmıştır. İstanbul kitabının temel düzey etkinliklerine bakıldığında da benzeri bir durum görülmektedir. Bu kitapta hazırlıksız konuşmalar; yol sorma, yol tarif etme, tanıtma, anma ve yıldönümü konuşmaları, sunuş konuşmaları, soru sorma ve sorulara cevap verme konuşmaları olmak üzere 5 farklı türde ele alınmıştır. Kitapta hazırlıklı konuşma örneği bulgulanmamıştır.

Tablo 2. Orta Düzey Yabancılara Türkçe Öğretimi Kitaplarından Konuşma Türlerinin Görünümü 


\begin{tabular}{|c|c|c|c|c|c|}
\hline HAZIRLIKLI & Y.iklim & İstanbul & HAZIRLIKSIZ & Y. İklim & İstanbul \\
\hline KONUŞMALAR & & & KONUŞMALAR & & \\
\hline Konferans & - & - & Kendini Tanıtma & - & - \\
\hline Münazara & - & - & Tanışma ve Tanıştırma & - & - \\
\hline Sempozyum & - & - & Teşekkür-Özür & - & - \\
\hline Panel & - & - & Telefonda Konuşma & - & - \\
\hline Forum & - & - & Ziyaret & - & - \\
\hline Açık Oturum & - & - & Karşılama ve Uğurlama & - & - \\
\hline Söylev & - & - & Selamlaşma Konuşmaları & - & - \\
\hline Röportaj & - & 1 & Yol Sorma, Yol Tarifi Konuşmaları & - & - \\
\hline \multirow[t]{8}{*}{ Mülakat } & - & - & Tanıtma Konuşmaları & 1 & 1 \\
\hline & & & Anma ve Yıldönümü Konuşmaları & 1 & - \\
\hline & & & Açış Konuşmaları & - & - \\
\hline & & & Sunuş Konuşmaları & 4 & 2 \\
\hline & & & Sohbet Konuşmaları & 3 & 6 \\
\hline & & & Fıkra Anlatmak & - & - \\
\hline & & & $\begin{array}{l}\text { Soru Sorma ve Sorulara Cevap } \\
\text { Verme Konuşmaları }\end{array}$ & 21 & 20 \\
\hline & & & Görevlilerle Yapılan Konuşmalar & 2 & - \\
\hline Toplam & 0 & 1 & Toplam & 32 & 29 \\
\hline
\end{tabular}

Orta düzey Yedi İklim kitaplarında hazırlıksız konuşmalar; tanıtma, anma ve yıldönümü konuşmaları, sunuş konuşmaları, sohbet konuşmaları, soru sorma ve sorulara cevap verme konuşmaları ve görevlilerle yapılan konuşmalar olmak üzere 6 farklı türde ele alınırken, hazırlıklı konuşmalara herhangi bir örnek etkinlik tespit edilmemiştir. İstanbul kitabının orta düzey etkinliklerine bakıldığında ise hazırlıksız konuşmalar; tanıtma konuşmaları, sunuş konuşmaları, sohbet konuşmaları ve soru sorma ve sorulara cevap verme konuşmaları olmak üzere 4 farklı türde ele alınmıştır. Kitapta yer alan tek hazırlıklı konuşma örneği ise röportaj türündedir.

Tablo 3. Ileri Düzey Yabancılara Türkçe Öğretimi Kitaplarında Konuşma Türlerinin Görünümü

\begin{tabular}{|c|c|c|c|c|c|}
\hline HAZIRLIKLI & Y.iklim & İstanbul & HAZIRLIKSIZ & Y. İklim & İstanbul \\
\hline KONUŞMALAR & & & KONUŞMALAR & & \\
\hline Konferans & 2 & - & Kendini Tanıtma & - & - \\
\hline Münazara & - & 3 & Tanışma ve Tanıştırma & - & - \\
\hline Sempozyum & 1 & - & Teşekkür-Özür & - & - \\
\hline Panel & - & - & Telefonda Konuşma & - & - \\
\hline Forum & - & - & Ziyaret & - & - \\
\hline Açık Oturum & - & - & Karşılama ve Uğurlama & - & - \\
\hline Söylev & - & - & Selamlaşma Konuşmaları & - & - \\
\hline Röportaj & - & 1 & Yol Sorma, Yol Tarifi Konuşmaları & - & - \\
\hline \multirow[t]{8}{*}{ Mülakat } & - & - & Tanıtma Konuşmaları & - & - \\
\hline & & & Anma ve Yıldönümü Konuşmaları & - & - \\
\hline & & & Açış Konuşmaları & - & - \\
\hline & & & Sunuş Konuşmaları & 1 & 5 \\
\hline & & & Sohbet Konuşmaları & 1 & 1 \\
\hline & & & Fikra Anlatmak & 1 & 1 \\
\hline & & & $\begin{array}{l}\text { Soru Sorma ve Sorulara Cevap } \\
\text { Verme Konuşmaları }\end{array}$ & 16 & 52 \\
\hline & & & Görevlilerle Yapılan Konuşmalar & 1 & 3 \\
\hline Toplam & 3 & 4 & Toplam & 20 & 63 \\
\hline
\end{tabular}


Ileri düzey Yedi Iklim kitaplarında hazırlıksız konuşmalar; sunuş konuşmaları, sohbet konuşmaları, fıkra anlatma, soru sorma ve sorulara cevap verme konuşmaları ve görevlilerle yapılan konuşmalar olmak üzere 5 farklı türde ele alınırken, hazırlıklı konuşmalar konferans ve sempozyum ile sınırlı kalmıştır. İstanbul kitabının ileri düzey etkinliklerine bakıldığında ise hazırlıksız konuşmalar; sunuş konuşmaları, sohbet konuşmaları, fıkra anlatma, soru sorma ve sorulara cevap verme konuşmaları ve görevlilerle yapılan konuşmalar olmak üzere 5 farklı türde ele alınmıştır. Kitapta yer alan hazırlıklı konuşma örnekleri ise münazara ve röportaj türündedir.

Tablo 4. Temel-Orta-Ileri Düzey Yedi Iklim Kitaplarında Konuşma Türlerinin Görünümü

\begin{tabular}{llll}
\hline HAZIRLIKLI & Y.íklim & HAZIRLIKSIZ & Y. İlim \\
KONUŞMALAR & & KONUŞMALAR \\
Konferans & 2 & Kendini Tanıtma & - \\
Münazara & - & Tanışma ve Tanıştırma & 3 \\
Sempozyum & 1 & Teşekkür-Özür & - \\
Panel & - & Telefonda Konuşma & - \\
Forum & - & Ziyaret & - \\
Açık Oturum & - & Karşılama ve Uğurlama & - \\
Söylev & - & Selamlaşma Konuşmaları & - \\
Röportaj & 1 & Yol Sorma, Yol Tarifi Konuşmaları & 2 \\
Mülakat & - & Tanıtma Konuşmaları & 3 \\
& & Anma ve Yıldönümü Konuşmaları & 1 \\
& & Açış Konuşmaları & - \\
& & Sunuş Konuşmaları & 5 \\
& & Sohbet Konuşmaları & 12 \\
& & Fikra Anlatmak & 1 \\
& & Soru Sorma ve Sorulara Cevap & 53 \\
& & Verme Konuşmaları & \\
Toplam & & Görevlilerle Yapılan Konuşmalar & 3 \\
\hline
\end{tabular}

Yedi İklim temel, orta ve ileri düzey kitaplarında yer alan hazırlıksız konuşmalar; tanışma ve tanıştırma konuşmaları, yol sorma ve yol tarifi konuşmaları, tanıtma konuşmaları, anma ve yıldönümü konuşmaları, sunuş konuşmaları, sohbet konuşmaları, fıkra anlatımı, soru sorma ve sorulara cevap verme konuşmaları ve görevlilerle yapılan konuşmalar olmak üzere 9 farklı türde ele alınırken, hazırlı konuşmalar; konferans, sempozyum ve röportaj ile sınırlı kalmıştır. Kitapta tespit edilen toplam hazırlıksız konuşma etkinliği 146 iken, hazırlıklı konuşma etkinlikleri ise sadece 4'tür.

Tablo 5. Temel-Orta-Illeri Düzey İstanbul Kitaplarında Konuşma Türlerinin Görünümü

\begin{tabular}{llll}
\hline HAZIRLIKLI & İstanbul & HAZIRLIKSIZ & İstanbul \\
KONUŞMALAR & & $\begin{array}{l}\text { KONUŞMALAR } \\
\text { Kendini Tanıtma }\end{array}$ & - \\
Konferans & - & Tanışma ve Tanıştırma & - \\
Münazara & 3 & Teşekkür-Özür & - \\
Sempozyum & - & Telefonda Konuşma & - \\
Panel & - & Ziyaret & - \\
Forum & - & Karşılama ve Uğurlama & - \\
Açık Oturum & - & Selamlaşma Konuşmaları & - \\
Söylev & - & Yol Sorma, Yol Tarifi Konuşmaları & 1 \\
Röportaj & 2 &
\end{tabular}




\begin{tabular}{|c|c|c|c|}
\hline \multirow[t]{8}{*}{ Mülakat } & - & Tanıtma Konuşmaları & 5 \\
\hline & & Anma ve Yıldönümü Konuşmaları & 1 \\
\hline & & Açış Konuşmaları & - \\
\hline & & Sunuş Konuşmaları & 9 \\
\hline & & Sohbet Konuşmaları & 7 \\
\hline & & Fıkra Anlatmak & 1 \\
\hline & & $\begin{array}{l}\text { Soru Sorma ve Sorulara Cevap } \\
\text { Verme Konuşmaları }\end{array}$ & 89 \\
\hline & & Görevlilerle Yapılan Konuşmalar & 3 \\
\hline Toplam & 5 & Toplam & 117 \\
\hline
\end{tabular}

İstanbul temel, orta ve ileri düzey kitaplarında yer alan hazırlıksız konuşmalar; yol sorma ve yol tarifi konuşmaları, tanıtma konuşmaları, anma ve yıldönümü konuşmaları, sunuş konuşmaları, sohbet konuşmaları, fıkra anlatımı, soru sorma ve sorulara cevap verme konuşmaları ve görevlilerle yapılan konuşmalar olmak üzere 8 farklı türde ele alınırken, hazırlı konuşmalar; münazara ve röportaj ile sınırlı kalmıştır. Kitapta tespit edilen toplam hazırlıksız konuşma etkinliği 117 iken, hazırlıklı konuşma etkinlikleri ise sadece $5^{\prime}$ tir.

Tablo 6. Temel-Orta-Ileri Düzey Kitap Setlerinde Konuşma Türlerinin Görünümü

\begin{tabular}{llll}
\hline HAZIRLIKLI & Y.iklim & HAZIRLIKSIZ & Y. İklim \\
KONUŞMALAR & İstanbul & KONUŞMALAR & İstanbul \\
Konferans & 2 & Kendini Tanıtma & - \\
Münazara & 3 & Tanışma ve Tanıştırma & 3 \\
Sempozyum & 1 & Teşekkür-Özür & - \\
Panel & - & Telefonda Konuşma & - \\
Forum & - & Ziyaret & - \\
Açık Oturum & - & Karşılama ve Uğurlama & - \\
Söylev & - & Selamlaşma Konuşmaları & - \\
Röportaj & 3 & Yol Sorma, Yol Tarifi Konuşmaları & 3 \\
Mülakat & - & Tanıtma Konuşmaları & 8 \\
& & Anma ve Yıldönümü Konuşmaları & 2 \\
& & Açı̧ Konuşmaları & - \\
& & Sunuş Konuşmaları & 14 \\
& & Sohbet Konuşmaları & 19 \\
& & Fıkra Anlatmak & 2 \\
& & Soru Sorma ve Sorulara Cevap & 141 \\
& & Verme Konuşmaları & \\
Toplam & & Görevlilerle Yapılan Konuşmalar & 6 \\
\hline & & Toplam & 200 \\
\hline
\end{tabular}

Yedi İklim ve İstanbul temel, orta ve ileri düzey kitaplarında görülen hazırlıklı konuşma türleri; tanışma ve tanıştırma, yol sorma ve yol tarifi konuşmaları, tanıtma konuşmaları, anma ve yıldönümü konuşmaları, sunuş konuşmaları, sohbet konuşmaları, fıkra anlatımı, soru sorma ve sorulara cevap verme konuşmaları ve görevlilerle yapılan konuşmalar olmak üzere 9 farklı türde ele alınırken, hazırlıklı konuşmalar; konferans, münazara, sempozyum, ve röportajdan oluşmuştur. Nicelik açısından bakıldığında ise hazırlıklı ve hazırlıksız konuşmalar arasında büyük bir fark görülmektedir. Kitaplarda bulgulanan hazırlıklı konuşma sayısı sadece 9 iken, hazırlıksız konuşma sayısı 200'dür. 


\section{Sonuç ve Öneriler}

a) Temel düzey ile ilgili sonuçlar:

1. Temel düzey Yedi iklim kitabında 9 hazırlıklı konuşma türünden sadece birine yer verilmiştir.

2. Temel düzey Yedi İklim kitabında 17 hazırlıksız konuşma türünden 5 'i etkinliklerde yer bulmuştur.

3. Temel düzey İstanbul kitabında 9 hazırlıklı konuşma türünden hiçbiri bulunmamaktadır.

4. Temel düzey İstanbul kitabında 17 hazırlıksız konuşma türünden $5^{\prime} \mathrm{i}$ etkinliklerde yer bulmuştur.

5. Temel düzey kitaplarında 9 hazırlıklı konuşma türünden sadece röportaja yer verilmiştir.

6. Temel düzey kitaplarından 17 hazırlıksız konuşma türünden; tanışma ve tanıştırma, yol sorma, yol tarif etme, sohbet konuşmaları, sunuş konuşmaları ve soru sorma, sorulara cevap verme konuşmaları olmak üzere 7 farklı konuşma türüne yerilmiştir.

b) Orta düzey ile ilgili sonuçlar:

1. Orta düzey Yedi İklim kitabında 9 hazırlıklı konuşma türünden hiçbirine yer verilmemiştir.

2. Orta düzey Yedi İklim kitabında 17 hazırlıksız konuşma türünden 6'sı etkinliklerde yer bulmuştur.

3. Orta düzey İstanbul kitabında 9 hazırlıklı konuşma türünden hiçbiri bulunmamaktadır.

4. Orta düzey İstanbul kitabından 17 hazırlıksız konuşma türünün 4'ü ile ilgili etkinliklere yer verilmiştir.

5. Orta düzey kitaplarında 9 hazırlıklı konuşma türünden sadece röportaja yer vermiştir.

6. Orta düzey kitaplarında 17 hazırlıksız konuşma türünden; tanıtma, anma ve yıldönümü konuşmaları, sunuş konuşmaları, sohbet konuşmaları, soru sorma ve sorulara cevap verme konuşmaları ve görevlilerle yapılan konuşmalar olmak üzere 6 farklı konuşma türüne yer vermiştir.

c) Illeri Düzey ile ilgili sonuçlar:

1. İleri düzey Yedi İklim kitabında 9 hazırlıklı konuşma türünden 3’ü ile ilgili etkinliklere yer verilmiştir.

2. Ileri düzey Yedi İklim kitabında 17 hazırlıksız konuşma türünden 5’i etkinliklerde yer bulmuştur. 
3. İleri düzey İstanbul kitabında 9 hazırlıklı konuşma türünden $4^{\prime}$ ü ile ilgili etkinliklere yer verilmiştir.

4. İleri düzey İstanbul kitabından 17 hazırlıksız konuşma türünün 5’i ile ilgili etkinliklere yer verilmiştir.

5.Ileri düzey kitaplarında 9 hazırlıklı konuşma türünden 4'ü ile ilgili etkinlikler vardır.

6. İleri düzey kitaplarında 17 hazırlıksız konuşma türünden; sunuş konuşmaları, sohbet konuşmaları, fıkra anlatma, soru sorma ve sorulara cevap verme konuşmaları ve görevlilerle yapılan konuşmalar olmak üzere 5 farklı konuşma türü etkinliği bulunmaktadır.

d) Genel sonuçlar:

1. Temel düzey ve orta düzeyde hazırlıklı konuşma örnekleri aynı sayıda kalırken, ileri düzey kitaplarında hazırlıklı konuşma örneklerinin çoğaldığı görülmektedir.

2. Temel, orta ve ileri düzey kitaplarda kendini tanıtma, teşekkür-özür konuşmaları, telefonda konuşma, ziyaret, karşılama ve uğurlama, selamlaşma konuşmaları, açış konuşmaları gibi hazırlıksız konuşma türlerine hiç yer verilmemiştir.

3. Temel, orta ve ileri düzey kitaplarda panel, forum, açık oturum, söylev ve mülakat gibi hazırlıklı konuşma türlerine hiç yer verilmemiştir.

3. Temel, orta ve ileri düzey kitaplarda hazırlık konuşmaların sayısı, hazırlıksız konuşmalara göre çok düşüktür. Bu kitaplarda toplam hazırlıklı konuşma etkinliği sayısı 9 iken, hazırlıksız konuşma etkinliği sayısı 200'dür.

Araştırma kapsamında ortaya konulan öneriler şunlardır:

- Yabancı dil olarak Türkçe öğretimi kitabında konuşma etkinliklerinin sayısı artırılmalıdır.

- Hazırlı ve hazırlıklı konuşma etkinliklerinde konuşma türlerine göre dağııımlar dengeli olmalıdır.

- Hazırlı ve hazırlıksız konuşmaların tüm alt türlerinden etkinliklere mümkün olduğunca kitaplarda yer verilmelidir.

\section{Kaynaklar}

Byrdon, S. R. ve Scott, M. D. (2008). Between one and many the art and science of public speaking. New York: Mcgraw-Hill Press.

CEF. (2002). Common european framework of reference for languages: Learning, teaching, assessment. Council of Europe, Strasbourg.

Demirel, Ö. (1999). İlköğretim okullarında Türkçe öğretimi. İstanbul: MEB Yayınevi. 
Demirel, Ö. (2011). Konuşma türleri. Türkçe sözlü anlatım. D. Belet (Ed). Eskiş̧ehir: Anadolu Üniversitesi Yayınları. Göğüş, B. (1978). Orta dereceli okullarımızda Türkçe ve yazın eğitimi. Ankara: Gül Yayıncılık.

Gülsevin, G. ve Boz, E. (2006). Türk dili ve kompozisyon 1-2. Konya: Tablet Yayınları.

Güneş, F. (2013). Türkçe öğretimi yaklaşımlar ve modeller. Ankara: Pegem Akademi.

Güneş, F. (2014). Konuşma öğretimi yaklaşım ve modelleri. Bartın Üniversitesi Eğitim Fakültesi Dergisi, 3(1), 1-27.

Karadüz, A. (2011). Konuşma eğitimi. Ankara: Pegem Akademi.

Kurudayığlu, M. (2013). Konuşma eğitimi. İstanbul: Kriter Yayınevi.

Laskowski, L. (2019) T. I. Q. S. - A way to a speaker's introduction, http://www.ljlseminars.com/keynotes.htm Erişim: 11.12.2017

Özkırımlı, A. (2002). Türk dili, dil ve anlatım. İstanbul: Bilgi Üniversitesi Yayınları.

Sağlam, Ö. (2010). 7. sınıf öğrencilerinin hazırlıksız konuşma becerileri üzerine bir araştırma. Yayınlanmamış Yüksek Lisans Tezi. Gazi Üniversitesi Eğitim Bilimleri Enstitüsü, Ankara.

Sert, G., Kurtoğlu, M, Akıncı, A. ve Seferoğlu, S. (2012). Öğretmenlerin teknoloji kullanma durumlarını inceleyen araştırmalara bir bakış: Bir içerik analizi çalışması. Akademik Bilişim Konferansı Bildirileri.

Sever, S. (1998). Dil ve iletişim. Ankara Üniversitesi Eğitim Bilimleri Fakültesi Dergisi. C.31 S.51-66.

Şimşek, H.A. (2004). ilköğretim ikinci kademe Türkçe öğretiminde konuşma becerisinin önemi ve geliştirme yolları. Yayımlanmamış Yüksek Lisans Tezi. Gazi Üniversitesi Eğitim Bilimleri Enstitüsü: Ankara.

Taşer, S. (2015). Konuşma eğitimi. İstanbul: Pegasus Yayınları.

Temizyürek, F. Erdem, İ. ve Temizkan, M. (2013). Konuşma eğitimi. Ankara: Pegem Akademi.

TDK (1996). Türkçe sözlük Ankara: Türk Dil Kurumu Yayınları.

Ünalan, Ş. (2007). Sözlü anlatım. Ankara: Nobel Yayın Dağıtım.

Yalçın, A. (2006). Türkçe öğretim yöntemleri yeni yaklaşımlar. Ankara: Akçağ Yayınları.

Yüceer, D. (2014). Türkçe öğretmenliği birinci sınıf öğrencilerinin hazırlıksız konuşma becerileri üzerine bir araştırma. Yayımlanmamış Yüksek Lisans Tezi. Gazi Üniversitesi Eğitim Bilimleri Enstitüsü: Ankara.

\section{Extended Abstract}

\section{Introduction}

Speaking education is important for individuals who can think and transfer their thoughts to people they communicate correctly and effectively. Accordingly, speaking skills in education need to be developed consciously and systematically. The same situation exists in teaching Turkish to foreigners. In teaching Turkish to foreigners, it is aimed to improve listening, reading and writing skills as well as speaking skills. Furthermore, it can even be said that speaking has a different and special place in all language skills in foreign language teaching. Because communication is often associated with speaking skills.

Types of speech are classified according to the specific purpose and function of the speech, the mode of presentation and the characteristics of the speaker-listener. When the researches about the types of speech are examined, it is seen that there is no consensus among the researchers on the classification of speech types. On one hand some researchers classify speech according to function, it is seen that some researchers classify speech as reciprocal and singular conversations, while some researchers classify the speech as persuasive and guided speech. On the other hand, some researchers, classify speech as prepared and unprepared speech. In this study, types of speech were examined in terms of presentation, and the two main headings, namely, prepared and unprepared speeches, were examined. The aim of this study is to figure out the type of activities created for speaking skills.

\section{Method}

This research is a qualitative study aiming to figure out the type of speaking activities designed for teaching speaking in book sets of teaching Turkish as a foreign language. In this research, document analysis was 
used to reach this aim and to collect data. The research object consists of A1 level books representing the basic level, B1 level books representing the intermediate level and C1 level books representing the advanced level from Yedi iklim Publishing and Istanbul Publishing sets. The data were analysed using content analysis. The findings were classified and interpreted by using frequency rates.

\section{Result and Discussion}

While basic and intermediate level prepared speaking activities show equal numbers quantitatively, it is seen that prepared speaking activities show an increase in advanced levels. Basic, intermediate and advanced level books do not include any kind of unprepared speaking such as introducing oneself, thank you-apology speeches, speaking on the phone, visiting, greeting speeches, presenting speeches. Prepared speaking activities such as panels, forums, open sessions, speeches and interviews are not included in the basic, intermediate and advanced books. The number of prepared speaking activities in basic, intermediate and advanced books is very low compared to unprepared speaking activities. While the total number of prepared speaking activities in these books is 9, the number of unprepared speaking activities is 200 .

The recommendations given within the scope of the research are as follows:

- The number of speaking activities should be increased in Teaching Turkish as a foreign language coursebooks.

- The distributions of prepared and unprepared speaking activities should be balanced according to the types of speech.

- Activities of all sub-types of prepared and unprepared speeches should be included in the books as much as possible. 